\title{
Identification of environmental factors explaining the total nitrogen concentration in mosses collected in the Moravian Silesian borderlands.
}

\author{
Irena Pavlíková, Vítězslav Plášek, Daniel Hladký, \\ Kateřina Tomšejová \& Petr Jančík
}

Identification of environmental factors explaining the total nitrogen concentration in mosses collected in the Moravian Silesian borderlands. - Acta Mus. Siles. Sci. Natur. 65: 235-242, 2016.

\begin{abstract}
Mosses as biomonitors of atmospheric nitrogen (N) deposition were collected from 41 locations in the Moravian Silesian borderlands. Total N concentrations were determined via elemental analysis. Site-specific and local factors were investigated using geostatistical and statistical analyses at a local scale. To assess the correlation between moss $\mathrm{N}$ concentrations and chosen factors, Spearman Rank Correlation Analysis was used. Then Exploratory Regression was applied in order to find the factors explaining the spatial distribution pattern of $\mathrm{N}$ concentrations. The correlation analysis for the chosen factors showed the strongest correlation between the total $\mathrm{N}$ concentrations in mosses and the 7-day precipitation $\left(r_{s}=-0.54\right)$, the Forested land use within $0.5 \mathrm{~km}$ radius around the site $\left(r_{s}=-0.33\right)$ and the Agricultural land use within $0.5 \mathrm{~km}$ radius around the site and $1 \mathrm{~km}$ respectively $\left(r_{s}=0.34\right.$ and $\left.r_{s}=0.31\right)$. The accurate regression model comprised four factors: the 7-day precipitation, the 3-month precipitation, Forested land use within $0.5 \mathrm{~km}$ radius and Agricultural land use within $0.5 \mathrm{~km}$ radius around the site, with calculated adjusted R-squared $=0.49$. Analyses also identified the dependence of the total $\mathrm{N}$ concentration on the moss species but the statistical data set is considered too small to make further conclusions.
\end{abstract}

Key words : nitrogen, moss, atmospheric deposition, the Moravian Silesian borderlands

\section{Introduction}

Bryophytes are small green land plants without true vascular system. They obtain nutrients directly from water solutions occurring in immediate vicinity. The substances are absorbed without selection directly by diffusion through the cells of the gametophyte. In this way, various types of pollutants also easily transfer into the plants. That is why the bryophytes have been used as reliable indicators of air pollution (LeBlanc \& Rao 1975). Suitable moss-bioindicators should be very sensitive to pollution and subsequently show visible symptoms caused by the effects of pollutants or should have the capacity to absorb and retain pollutants in quantities much higher than those absorbed by other plant groups growing in the same habitat. Both types of indicators are therefore frequently used to evaluate the state of environmental pollution or confirmation of the presence/absence of various pollutants.

Anthropogenic nitrogen deposition poses a global threat to ecosystems and their floral diversity (Sala et al. 2000; Phoenix et al. 2006). While many researches have focused on the responses of higher plants, bryophytes have received far less attention despite these being significant components of many ecosystems. As for effects of nitrogen on mosses, it seems that different moss species have unequal abilities to bind atmospheric nitrogen in their cells. It was found that atmospheric nitrogen deposition can cause major declines in bryophyte abundance yet the physiological basis for such declines is not fully understood. ( $c f$. Harmens et al. 2014; Solga et al. 2005; Varela et al. 2013). In particular, the concentration of nitrogen in the environment is a significant environmental variable (Schröder et al. 2014; Skudnik et al. 2015) and can help to identify areas at risk from high atmospheric nitrogen deposition at a high spatial resolution (Harmens et al. 2011, 2013; Schröder et al. 2010). 


\section{Material and methods}

\section{Sampling and chemical analysis of mosses}

The moss samples were collected in October 2015 from 41 sites in the Moravian Silesian region - the Czech-Polish borderlands at the area of $1600 \mathrm{~km}^{2}(40 \mathrm{~km}$ x $40 \mathrm{~km})$. All the sampling sites were located on a regular $10 \times 10 \mathrm{~km}$ mesh with an extra point in the centre of each square (Fig 1).

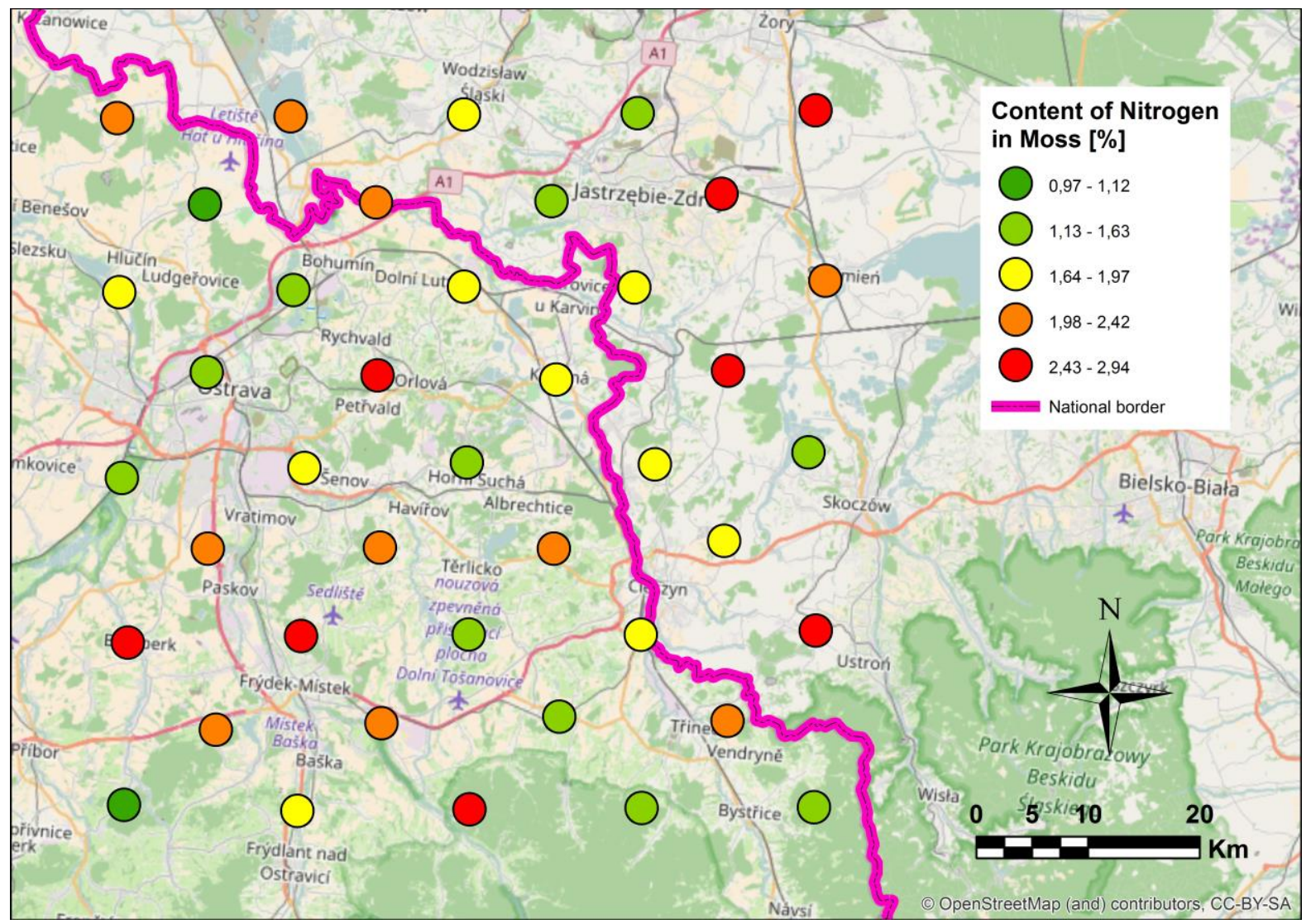

Fig 1: Nitrogen concentration at sample sites

The sampling was carried out according to the Monitoring Manual established by the International Cooperative Programme on Effects of Air Pollution on Natural Vegetation and Crops (ICP Vegetation 2015): Heavy metals, nitrogen and POPs in European mosses: 2015 survey (Harmens \& Frontasyeva 2014). In frame of this program, the European moss survey has been conducted every five years since 1990 (Harmens 2008a). The $\mathrm{N}$ concentration in mosses has been determined within this program since 2005 (Harmens \& Frontasyeva 2014).

According to the Manual, pleurocarpous mosses are preferred for the determination of atmospheric deposition. The most frequent and sampled moss species in the area of interest was Brachythecium rutabulum (56\% of all samples). This moss species grows in areas affected by anthropogenic activity (Sucharová et al. 2008). Brachythecium rutabulum however, did not occur at all sites; therefore, following moss species were collected to complete the grid: Hypnum cupressiforme, Rhytidiadelphus squarrosus, Hylocomium splendens, Eurhynchium hians, Cirriphyllum piliferum, Calliergonella cuspidata and Brachythecium salebrosum.

To obtain the $\mathrm{N}$ content, mosses were dried at $80^{\circ} \mathrm{C}$ for $24 \mathrm{~h}$, processed in an agate mill ( $\left.3 \mathrm{~min}, 350 \mathrm{rpm}\right)$ to assure the sample homogeneity and determined via elemental analysis on Leco CHN628 following Dumas method (Dumas 1893). Preceding the chemical analysis, the mosses were cleaned and tree-year growths were separated and submitted to the analysis.

\section{Environmental factors}

This paper focuses on the examination of environmental factors that influence the $\mathrm{N}$ concentrations in mosses. According to the literature, the set of environmental factors, which might explain the spatial variability, was prepared and used for further analyses (Pesch et al. 2008; Schröder et al. 2010; Skudnik et al. 2015, 2016). Two site-specific factors and 19 local characteristics were taken into account. For list of the factors, see Table 1. 
Table 1: Environmental factors datasets used for analyses

\begin{tabular}{|c|c|c|}
\hline Factor & Resolution & Data Source \\
\hline Moss species & Site-specific & \\
\hline Altitude & Site-specific & \\
\hline Long-term precipitation $(1,3,6,9$ months $)$ & $10 \mathrm{~m} \times 10 \mathrm{~m}$ & CHMI, NOAA, InMeteo \\
\hline Short-term precipitation $(1,3,7$ days $)$ & $10 \mathrm{~m} \times 10 \mathrm{~m}$ & NOAA, InMeteo \\
\hline Agricultural land use $(0.5,1,5,10 \mathrm{~km}$ radius $)$ & $10 \mathrm{~m} \times 10 \mathrm{~m}$ & EEA \\
\hline Forested land use $(0.5,1,5,10 \mathrm{~km}$ radius $)$ & $10 \mathrm{~m} \times 10 \mathrm{~m}$ & EEA \\
\hline Urban land use $(0.5,1,5,10 \mathrm{~km}$ radius $)$ & $10 \mathrm{~m} \times 10 \mathrm{~m}$ & EEA \\
\hline
\end{tabular}

The long-term precipitation data (1, 3, 6 and 9 months before sampling) were delivered by the Czech Hydrometeorological Institute (CHMI). These data comprised 20 meteorological stations across the area of interest (CHMI 2016). They were supplemented with open source data from 36 other stations, which National Oceanic and Atmospheric Administration (NOAA 2015) and InMeteo (InMeteo 2016) provide on their websites. The short-term precipitation data (1,3 and 7 days before sampling) were obtained from the same 36 stations and were exclusively from open sources (NOAA 2015; InMeteo 2016). With the use of "Inverse distance weighted" (IDW) interpolation tool for spatial interpolation (Watson \& Philip 1985) in ArcMap 10.3, rasters with $10 \mathrm{~m}$ resolution were created for specified monthly and daily precipitations (Skudnik et al. 2015).

The percentage of the site surrounding land use was calculated from the Corine Land Cover dataset (EEA, 2012) using the "Focal statistics" tool in ArcMap 10.3 (ESRI 2011). This tool calculates a statistics of values within a specified neighbourhood around it for each cell in a raster file. For this purpose, Corine Land Cover vector data were selected according to the required land use and converted to raster with $10 \mathrm{~m}$ resolution. Then the percentage of the total area covered by the selected land use type within the specified radius was calculated.

\section{Statistical analysis}

Prior to the statistical analysis, the measured $\mathrm{N}$ concentrations were investigated via geostatistics using the "Spatial Autocorrelation" tool in ArcMap 10.3 (Wong \& Lee 2005). The tool determines spatial autocorrelation based on feature locations and attribute values using the Global Moran's I statistics. Moran's Index evaluates whether the pattern is clustered, dispersed, or random. A positive Moran's I index value indicates tendency toward clustering, a negative Moran's I index value indicates tendency toward dispersion.

To indicate the strength and direction of association between the $\mathrm{N}$ concentrations in mosses and investigated environmental factors, bivariate correlation coefficients were computed. Because the $\mathrm{N}$ concentrations and most of the factors proved to be not normally distributed, the Spearman rank correlation coefficient $r_{s}$ was used for the evaluation (Perch et al. 2007; Schröder et al. 2010). This coefficient indicates the correspondence between two data sets and determines its statistical significance. The correlation coefficient $r_{s}$ assume values from -1 to 1 . If $r_{s}=-1$, two ranks are in absolute negative association, if $r_{s}=0$, the ranks are independent and if $r_{s}=1$, the ranks are perfectly associated (Schröder et al. 2010). So $r_{s}$ values close to 0 indicates weak association between ranks. The classification of the strength of correlation was accepted the same as presented in Schröder et al. 2010. The correlation coefficient values $r_{\mathrm{s}}<|0.2|$ are very low, between $|0.2|$ and $|0.5|$ low, from $|0.5|$ to $|0.7|$ moderate, between $|0.7|$ and $|0.9|$ high and $>|0.9|$ very high.

To explain the spatial distribution pattern of the total $\mathrm{N}$ concentrations in mosses it is necessary to choose from a set of potential explanatory variables the ones which have the most important significance. This was done applying "Exploratory Regression" tool in ArcMap 10.3 (Braun \& Oswald 2011). It is a data mining tool that tries all possible combinations of explanatory variables to find out which models pass all of the necessary Ordinary Least Squares (OLS) diagnostics. To optimize the process Minimum Acceptable Adjusted $R^{2}$ was set at 0.05, Maximum Coefficient p-value Cutoff 0.01, Maximum Variance Inflation Factor Value Cutoff 7.5, Minimum Acceptable Jarque Bera p-value 0.1 and Minimum Acceptable Spatial Autocorrelation p-value 0.1.

All the analyses were run for the whole set of data and after just for samples of Brachythecium rutabulum exclusively. While these dataset being small (27 observations) the results are not presented in detail.

\section{Results}

The minimum measured value of the $\mathrm{N}$ concentration is $9.7 \mathrm{mg} / \mathrm{g}$, the maximum value $29.4 \mathrm{mg} / \mathrm{g}$ and the average concentration of the total $\mathrm{N}$ in mosses in the monitored area of the Moravian Silesian region is $19.6 \mathrm{mg} / \mathrm{g}$.

Determined Moran's I index value in the geostatistical assessment was 0.01 , so the spatial distribution pattern of the $\mathrm{N}$ concentration in mosses does not appear to be significantly 
different than random. The calculated z-score of 0.27 and $p$-value of 0.79 indicates no spatial autocorrelation.

The Spearman rank correlation analysis showed statistically significant relation ( $p$-value $<0.05$ ) of the total $\mathrm{N}$ concentrations in mosses with four environmental factors: 7-day precipitation, forested land use within $0.5 \mathrm{~km}$ radius and agricultural land use within $0.5 \mathrm{~km}$ radius and $1 \mathrm{~km}$ respectively. The strongest observed relation was a moderate negative association with 7-day precipitation $\left(r_{s}=-0.54\right)$. Regarding to the local land use characteristics, Forested land use within $0.5 \mathrm{~km}$ radius had low negative association $\left(r_{s}=-0.33\right)$ and Agricultural land use within $0.5 \mathrm{~km}$ and $1 \mathrm{~km}$ radius low positive association $\left(r_{s}=0.34\right.$ and $\left.r_{s}=0.31\right)$. Table 2 provides more detail information (factors with $p$-value < 0.05 are in bold).

Table 2: Spearman rank correlation coefficients between total $\mathrm{N}$ concentration in mosses and environmental factors

\begin{tabular}{|c|c|c|}
\hline Factor & Abbreviation used & $r_{s}(p<0.05)$ \\
\hline Altitude & ALT & 0.10 \\
\hline Agricultural land uses $-0.5 \mathrm{~km}$ radius & ALU05 & 0.34 \\
\hline Agricultural land uses - $1 \mathrm{~km}$ radius & ALU1 & 0.31 \\
\hline Agricultural land use $-5 \mathrm{~km}$ radius & ALU5 & 0.18 \\
\hline Agricultural land use - $10 \mathrm{~km}$ radius & ALU10 & 0.16 \\
\hline Forested land uses $-0.5 \mathrm{~km}$ radius & FLU05 & -0.34 \\
\hline Forested land use $-1 \mathrm{~km}$ radius & FLU1 & -0.27 \\
\hline Forested land use $-5 \mathrm{~km}$ radius & FLU5 & -0.03 \\
\hline Forested land use $-10 \mathrm{~km}$ radius & FLU10 & 0.01 \\
\hline Urban land use $-0.5 \mathrm{~km}$ radius & ULU05 & 0.07 \\
\hline Urban land use $-1 \mathrm{~km}$ radius & ULU1 & 0.06 \\
\hline Urban land use $-5 \mathrm{~km}$ radius & ULU5 & -0.06 \\
\hline Urban land use $-10 \mathrm{~km}$ radius & ULU10 & -0.11 \\
\hline Short-term precipitation - 1 day & STP1 & -0.02 \\
\hline Short-term precipitation - 3 days & STP3 & -0.28 \\
\hline Short-term precipitation - 7 days & STP7 & -0.54 \\
\hline Long-term precipitation - 1 month & LTP1 & 0.18 \\
\hline Long-term precipitation - 3 months & LTP3 & 0.14 \\
\hline Long-term precipitation - 6 months & LTP3 & 0.08 \\
\hline Long-term precipitation - 9 months & LTP9 & 0.12 \\
\hline
\end{tabular}

The Explanatory regression did not identify any models passing all of the set criterions. However 3 models were taken into consideration as adjusted $R^{2}$ values were close to 0.5 and model variable significance was smaller than 0.01 within the majority of explanatory factors (see Table 3). As the diagnostic parameters for the models listed in Table 3 reached comparable values, the best model was chosen depending on explaining variables. The criterion was variable significance and stability of relation direction with depending variable (negative or positive). Comparatively to other variables within the chosen models, the variables Altitude and Urban land use within $0.5 \mathrm{~km}$ radius has the lowest significance and the direction of the relation is not clearly unambiguous. See Table 4. Hence as the best model explaining the spatial variability of the $\mathrm{N}$ concentrations in mosses, the model at the second row in Table 3 is preferred. The variables 7-day precipitation, 3-month precipitation, Agricultural land use within $1 \mathrm{~km}$ radius and Forested land use within $0.5 \mathrm{~km}$ radius are supposed to explain the best special variability of the total $\mathrm{N}$ concentrations in mosses in the area of interest.

Statistical and geostatistical analyses carried out on the samples of Brachythecium ruthabulum solely got very similar results with some exceptions. The analyses showed the significance of Urban land use factor to the exclusion of Forested land use. The best model of 
adjusted $\mathrm{R}^{2}=0.47$ was with variables 7-day precipitation, 3-month precipitation and Agricultural land use within $5 \mathrm{~km}$ radius.

Table 3: Highest Adjusted $R^{2}$ Results

\begin{tabular}{lllllll}
\hline OLS Model & $\operatorname{AdjR}^{2}$ & $\mathrm{AICc}$ & $\mathrm{JB}$ & $\mathrm{K}(\mathrm{BP})$ & $\mathrm{VIF}$ & $\mathrm{SA}$ \\
\hline +ALT $* * *$-STP7 $* * *+A L U 1 * *$-FLU05*** & 0.50 & 38.31 & 0.68 & 0.15 & 1.95 & 0.82 \\
+LTP3*** -STP7*** + ALU1** - FLU05*** & $\mathbf{0 . 4 9}$ & $\mathbf{3 9 . 1 2}$ & $\mathbf{0 . 8 5}$ & $\mathbf{0 . 1 9}$ & $\mathbf{1 . 6 3}$ & $\mathbf{0 . 7 2}$ \\
+LTP3 $* * *$-STP7*** + ALU05*** +ULU05*** & 0.48 & 39.26 & 0.76 & 0.31 & 1.57 & 0.93 \\
\hline
\end{tabular}

Table Abbreviations:

OLS model Ordinary Least Squares model

$\operatorname{AdjR}^{2} \quad$ Adjusted R-Squared

AICc Akaike's Information Criterion

JB Jarque-Bera $p$-value

$\mathrm{K}(\mathrm{BP}) \quad$ Koenker's studentized Breusch-Pagan $p$-value

VIF Maximum Variance Inflation Factor

SA Global Moran's I $p$-value (a measure of residual spatial autocorrelation)

Model Variable direction (+/-)

Model Variable significance $(*=0.10, * *=0.05, * * *=0.01)$

Table 4: Summary of Variable Significance

\begin{tabular}{lrrr}
\hline Variable & Significant [\%] & Negative [\%] & Positive [\%] \\
\hline STP7 & 100.00 & 100.00 & 0.00 \\
ALU05 & 24.53 & 0.45 & 99.55 \\
FLU05 & 23.47 & 96.47 & 3.53 \\
ALU1 & 19.80 & 2.13 & 97.87 \\
LTP3 & 13.44 & 0.00 & 100.00 \\
FLU1 & 6.44 & 85.85 & 14.15 \\
ULU05 & 3.91 & 19.17 & 80.83 \\
ALT & 3.11 & 23.34 & 76.66 \\
\hline
\end{tabular}

\section{Discussion}

The detected total $\mathrm{N}$ concentration in mosses collected in the Moravian Silesian region within our experiment were higher than values detected in this region within the ICP Vegetation survey 2010/2011 (Harmens et al. 2013). According to the published map, the values in the area were in between 1.6 - 1.8\% mass or $>1.8 \%$ mass respectively (Harmens $e t$ al. 2013). The average value detected within our experiment in the area was $2.0 \%$ mass. There are two possible explanations of this fact. Either the total $\mathrm{N}$ concentration rises in the time, or the difference is caused by the divergent absorption of nitrogen by moss species. Mosses collected within our experiment (mostly Brachythecium rutabulum and Hypnum cupressiforme) contain generally more nitrogen than those ones collected within the survey (Pleurozium schreberi, Hylocomium splendens), presented in Harmens et al. 2011, Schröder et al. 2010 and Sucharová et al. 2008. As the data from the ICP Vegetation survey for 2015 has not been available while publishing the article, it is not easy to stick to concrete explanation. However, as the total $\mathrm{N}$ concentration in mosses declines across the Europe (Harmens et al. 2015), we presume that the difference is caused by the different moss species being sampled.

Applied analyses revealed the strongest and definite relation between the $\mathrm{N}$ concentrations and 7-day precipitation. Spearman rank correlation coefficient was $r_{s}=-0.54$ and significance of this variable in exploratory regression $100 \%$ (in negative direction). The positive relation between long-term precipitation (monthly and more) and the total $\mathrm{N}$ concentration in mosses is proved (Kalina et al. 2002; Miller et al. 1993; Pesch et al. 2008; 
Schröder et al. 2010; Skudnik et al. 2014, 2015, 2016). Also within our experiment, 3-months precipitation was determined in exploratory regression as an important variable for fitting the model. However, the effect of short-term precipitation is not discussed in the literature. We suggest that 7-day precipitation might cause the washing out of the dry deposition stacked on a moss surface and the effect might be connected with the intensity of precipitation but the problem can be much more complex (as presents for ex. Markham 2009). Therefore, it needs to be investigated closer to confirm the importance and define some valid conclusions.

As in the case of studies made on national or European scales, a strong dependence of the $\mathrm{N}$ concentration in mosses on the type of surrounding land use, especially agricultural and forest land use, was identified within our area of interest (Pesch et al. 2008; Schröder et al. 2010; Skudnik et al. 2016). Agricultural land use has positive effect on the $\mathrm{N}$ concentration in mosses while forest land use negative. The effect of agricultural land use on the $\mathrm{N}$ concentration is most likely connected with the fact that mosses generally take nitrogen in ammonium form (Harmens et al. 2008b; Schröder et al. 2010) and might be reinforced by the uptake of nitrogen dissolved from the top soil layer during periods with intensive rainfalls (Glime 2006). The opposite effect of forestland to $\mathrm{N}$ concentrations in mosses might be explained by the canopy drip effect (De Schrijver et al. 2008; Skudnik et al. 2016) or by the effect of different biodiversity of the ecosystem (Harmens et al. 2011).

The analyses carried out on the samples of Brachythecium rutabulum exclusively showed that the significance of the factors changes with species of moss (Pesch et al. 2008; Schröder et al. 2010). To study the special distribution of the $\mathrm{N}$ concentration in mosses in a regional scale, collecting one moss species would be preferable.

We are aware that the methods, we employed for data exploration, have their limitations. To avoid creating a model that fit only our data we selected candidate explanatory regression variables that are supported by theoretical background (Pesch et al. 2008; Schröder et al. 2010; Skudnik et al. 2014, 2015, 2016) although exclusively environmental factors were tested to explain the total nitrogen concentration in mosses collected in the Moravian Silesian borderlands.

According to the obtained results, we presume that the $\mathrm{N}$ concentrations in the mosses might be predicted on the regional scale with sufficient probability but only environmental factors are not able to explain enough of the spatial variability. As the data about wet and dry $\mathrm{N}$ deposition (Harmens 2011; Schröder et al. 2010) are not available for the regional scale in sufficient resolution, the variables that would represent it has to be used instead. To alternate the deposition data, we suggest defining of the emission load of the area for $\mathrm{NO}_{\mathrm{x}}$ and $\mathrm{NH}_{3}$ in detail, comprising the emission from housing, transport, industry and agriculture. Together with meteorological characteristics, these might be able to compile a valid model for the prediction.

Acknowledgements: The chemical analyses of the total $\mathrm{N}$ concentration in mosses were done under the financial support of the VŠB - Technical University of Ostrava student grant: "Thermal waste treatment and environmental protection II", no SP2016/62. The moss sampling was done under the financial support of 3+3 project for bilateral cooperation between VŠB - Technical university of Ostrava and Joint Institute of Nuclear Research in Dubna: "Air pollution characterization in Moravian Silesian region using nuclear and related analytical techniques and GIS Technology", no 03-4-1104. We would like to thank Z. Fedičová and K. Tomšejová for their help with moss sampling and cleaning. Thank to Institute of Environmental Technology for providing the devices for elemental analyses and Dr A. Prysz for the technical support. Moreover, special thanks to Dr M. Skudnik from the Slovenian Forestry Institute for his consultations. The contribution by V. Plášek is part of a research project of the Institute of Environmental Technologies, reg. no. CZ.1.05/2.1.00/03.0100, Project LO1208 of the National Feasibility Programme I of the Czech Republic. 


\section{References}

Braun M.T. \& Oswald F.L. (2011): Exploratory regression analysis: A tool for selecting models and determining predictor importance. - Behavior research methods 43(2): 331-339.

CHMI (2016): Month precipitation for 1-12/2013, 1-12/2014 and 1-9/2015 (20 stations). Czech Hydrometeorological Institute, Ostrava, CR.

De Schrijver A., Staelens J., Wuyts K., Van Hoydonck G., Janssen N., et al. (2008): Effect of vegetation type on throughfall deposition and seepage flux. - Environmental Pollution 153(2): 295-303.

Dumas J.B.A. (1831): Procedes de l'analyse organique. - Annales de Chimie et de Physique 247: 198-213.

EEA (2012): Corine Land Cover 2012 vector data. European Environmental Agency. Available from: http://land.copernicus.eu/pan-european/corine-land-cover.

ESRI (2011): In: Redlands (Ed.), ArcGIS Desktop: Release 10. Environmental Systems Research Institute, CA.

Glime J.M. (2007): Bryophyte ecology, vol 1. Physiological ecology. Ebook sponsored by Michigan Technological University and the International Association of Bryologists.

Harmens H. \& Frontasyeva M. (2014): Heavy metals, nitrogen and POPs in European mosses: 2015 survey. ICP Vegetation Programme Coordination Centre, CEH Bangor, UK. Available from: http://icpvegetation. ceh.ac.uk/publications/documents/MossmonitoringMANUAL-2015-17.07.14.pdf.

Harmens H. \& Norris D. (2008a): Spatial and temporal trends in heavy metal accumulation in mosses in Europe (1990-2005): Programme Coordination centre for the ICP Vegetation, Centre for Ecology and Hydrology.

Harmens H., Norris D., Cooper D. \& Hall J. (2008b): Spatial trends in nitrogen concentrations in mosses across Europe in 2005/2006.

Harmens H., Norris D.A., Cooper D.M., Mills G., Steinnes E., et al. (2011): Nitrogen concentrations in mosses indicate the spatial distribution of atmospheric nitrogen deposition in Europe. - Environmental Pollution 159(10): 2852-2860.

Harmens H., Norris D.A., Mills G., et al. (2013): Heavy metals and nitrogen in mosses: spatial patterns in 2010/2011 and longterm temporal trends in Europe. ICP Vegetation Programme Coordination Centre, CEH Bangor, UK. ISBN: 978-1-906698-38-6. Available from: http://icpvegetation.ceh.ac.uk.

Harmens H., Norris D.A., Sharps K., Mills G., Alber R., et al. (2015): Heavy metal and nitrogen concentrations in mosses are declining across Europe whilst some "hotspots" remain in 2010. - Environmental Pollution 200: 93-104.

Harmens H., Schnyder E., Thöni L., Cooper D.M., Mills G., et al. (2014): Relationship between sitespecific nitrogen concentrations in mosses and measured wet bulk atmospheric nitrogen deposition across Europe. - Environmental Pollution 194: 50-59.

In Lee K. \& Koval J.J. (1997): Determination of the best significance level in forward stepwise logistic regression. - Communications in Statistics-Simulation and Computation 26(2): 559-575.

In Meteo (2016): Archiv počasí, klima České republiky. InMeteo, Prague, CR. Available from: http://www.inpocasi.cz/archiv/.

Kalina M.F., Stopper S., Zambo E. \& Puxbaum H. (2002): Altitude-dependent wet, dry and occult nitrogen deposition in an alpine region. - Environmental Science and Pollution Research 9(2): 16-22.

LeBlanc F. \& Rao D.N. (1975): Effects of air pollution on Lichens and Bryophytes. Pp. 237-272. In: Mudd J.B. \& Kozlowski T.T. Responses of plants to air pollution. Academic Press, New York.

Markham J.H. (2009): Variation in moss-associated nitrogen fixation in boreal forest stands. - Oecologia 161(2): 353-359.

Miller E.K., Friedland A.J., Arons E.A., Mohnen V.A., Battles J.J., et al. (1993): Atmospheric deposition to forests along an elevational gradient at Whiteface Mountain, NY, USA. Atmospheric Environment. Part A. - General Topics 27(14): 2121-2136.

NOAA (2015): Daily observational data. National Oceanic and Atmospheric Administration, US. Available from: http://gis.ncdc.noaa.gov/.

Pesch R., Schroder W. \& Schmidt G. (2007): Nitrogen accumulation in forests. Exposure monitoring by mosses. - Sci. World J. 1: 151-158.

Pesch R., Holy M. \& Schröder W. (2008): Statistical investigation of the atmospheric accumulation of antimony and nitrogen in mosses. In: Geospatial Crossroads@GI_Forum'08: Proceedings of the Geoinformatics Forum Salzburg, Wichmann, Heidelberg: pp. 227-236.

Phoenix G.K., Hicks W.K., Cinderby S., Kuylenstierna J.C.I., Stock W.D., et al. (2006): Atmospheric nitrogen deposition in world biodiversity hotspots: the need for a greater global perspective in assessing $\mathrm{N}$ deposition impacts. - Global Change Biology 12: 470-476.

Sala O.E., Chapin F.S., Armesto J.J., Berlow E., Bloomfield J., et al. (2000): Biodiversity - global biodiversity scenarios for the year 2100. - Science 287: 1770-1774.

Schröder W., Holy M., Pesch R., Harmens H., Fagerli H., et al. (2010): First Europe-wide correlation 
analysis identifying factors best explaining the total nitrogen concentration in mosses. - Atmospheric Environment 44(29): 3485-3491.

Schröder W., Nickel S., Schönrock S., Meyer M., Wosniok W., et al. (2016): Spatially valid data of atmospheric deposition of heavy metals and nitrogen derived by moss surveys for pollution risk assessments of ecosystems. - Environmental Science and Pollution Research 2016: 1-20.

Schröder W., Pesch R., Schönrock S., Harmens H., Mills G., et al. (2014): Mapping correlations between nitrogen concentrations in atmospheric deposition and mosses for natural landscapes in Europe. Ecol. Indic. 36: 563-571.

Skudnik M., Jeran Z., Batič F., Simončič P., Lojen S. \& Kastelec D. (2014): Influence of canopy drip on the indicative $\mathrm{N}, \mathrm{S}$ and $\delta 15 \mathrm{~N}$ content in moss Hypnum cupressiforme. - Environmental Pollution 190: 27-35.

Skudnik M., Jeran Z., Batič F. \& Kastelec D. (2016): Spatial interpolation of N concentrations and $\delta 15 \mathrm{~N}$ values in the moss Hypnum cupressiforme collected in the forests of Slovenia. - Ecological Indicators 61: 366-377.

Skudnik M., Jeran Z., Batič F., Simončič P. \& Kastelec D. (2015): Potential environmental factors that influence the nitrogen concentration and drip $\delta^{15} \mathrm{~N}$ values in the moss Hypnum cupressiforme collected inside and outside canopy drip lines. - Environ. Pollut. 198: 78-85.

Solga A., Burkhardt J., Zechmeister H.G. \& Frahm J.P. (2005): Nitrogen content, ${ }^{15} \mathrm{~N}$ natural abundance and biomass of the two pleurocarpous mosses Pleurozium schreberi (Brid.) Mitt. and Scleropodium purum (Hedw.) Limpr. in relation to atmospheric nitrogen deposition. - Environ. Pollut. 134: 465-473.

Sucharová J., Suchara I., \& Holá M. (2008): Contents of 37 elements in moss and their temporal and spatial trends in the Czech Republic during the last 15 years: fourth Czech bio-monitoring survey pursued in the framework of the international programme UNECE ICP-Vegetation 2005/2006. Průhonice: VÚ Silva Taroucy pro krajinu a okrasné zahradnictví.

Thompson B. (1995): Stepwise regression and rtepwise discriminant analysis need not apply here: A guidelines editorial. - Educational and Psychological Measurement 55(4): 525-534.

Varela Z., Carballeira A., Fernández J.A. \& Aboal J.R. (2013): On the use of epigaeic mosses to biomonitor atmospheric deposition of Nitrogen. - Arch. Environ. Contam. Toxicol. 64: 562-572.

Watson D.F. \& Philip G.M. (1985): A Refinement of Inverse Distance Weighted Interpolation. - Geoprocessing 2: 315-327.

Wong W.S.D. \& Lee J. (2005): Statistical analysis of geographic information with ArcView GIS and ArcGIS. Wiley.

Authors' addresses: Irena Pavlíková, Dept. of Environmental Protection in Industry, VŠB - Technical University of Ostrava, 17. listopadu 15/2172, 70833 Ostrava, Czech Republic.

Email: irena.pavlikova@vsb.cz

Vítězslav Plášek, Dept. of Biology and Ecology, University of Ostrava, Chittussiho 10, CZ-710 00 Ostrava, Czech Republic.

E-mail: vitezslav.plasek@osu.cz

Daniel Hladký, Dept. of Environmental Protection in Industry, VŠB - Technical University of Ostrava, 17. listopadu 15/2172, 70833 Ostrava, Czech Republic.

Email: daniel.hladky@vsb.cz

Kateřina Tomšejová, VŠB - Technical University of Ostrava, 17. listopadu 15/2172,

70833 Ostrava, Czech Republic.

Email: katerina.tomsejova.st@vsb.cz

Petr Jančík, Dept. of Environmental Protection in Industry, VŠB - Technical University of Ostrava, 17. listopadu 15/2172, 70833 Ostrava, Czech Republic.

Email: petr.jancik@vsb.cz 